\title{
USING AHP TO DETERMINE MOTIVATIONAL FACTORS DRIVING VOLUNTEERISM IN SPORTS: NIGERIA OLYMPIC SPORT FEDERATIONS EXPERIENCE
}

\author{
Sikuade Oladimeji Jagun \\ Sol Simon Investments; E-mail: sjagun@yahoo.com \\ Bolajoko Nkemdinim Dixon-Ogbechi \\ University of Lagos, Lagos, Nigeria; E-mail: dixonogbechi@yahoo.com \\ Elizabeth Marie Haran \\ Salem State University, Salem, MA, USA; E-mail:eharan@salemstate.edu
}

\begin{abstract}
Most scholars are of the view that volunteers are individuals who willingly gave unpaid help, in the form of time, service or skills, through an organization or group. Despite this "consensus", some other scholars observed that contrary to this view, in Nigeria, some of the sports volunteers always expect financial rewards for services rendered. Thus this study used the AHP model to determine the motivational factors driving volunteerism in sports in Nigeria by focusing on the Nigeria Olympic Sport Federations. It adopted the survey research method to study a sample of 14 out of the 23 Nigeria Sport Federations in different cities in Nigeria. Our findings revealed that sports volunteers are mostly motivated by altruistic value, love of the sports, rewards (financial, personal) and personal development (skill, career).
\end{abstract}

Keywords: Volunteerism, Motivational factors, Nigeria Olympic Sports Federations, Analytic Hierarchy Process (AHP) model.

\section{Introduction}

Wang (2004) submitted that every day around the world, countless volunteers from all walks of life share their time, skill, and energy to help those in need. Yet despite the consensual definition of volunteers by scholars as people rendering services with no expectation of pay, evidence abound that Nigerian volunteers expect payment before, during or after organised sporting events (Elendu and Ogujiofor 2012). Given this controversy, this study sought to investigate the motivational factors driving volunteerism in the Nigeria Olympic Sporting Federations. To this effect, the following research questions are formulated:

i. What are the motivational factors driving volunteerism in the Nigeria Olympic Sport Federations?

ii. What is the relative importance of the motivational factors driving volunteerism in the Nigeria Olympic Sport Federations?

A study of this nature is important because it will add to the body of knowledge on sports administration and volunteerism in the Nigerian sporting environment.

\section{Literature Review}


ISAHP Article: Jagun, Dixon-Ogbechi \& Haran/Using AHP to Determine the Motivational Factors Driving Volunteerism in Sports: The Nigeria Olympic Sports Federations Experience Submitted to the International Symposium of the Analytic Hierarchy Process 2016, London, UK.

This study reviewed the works on volunteerism of scholars like Elendu and Ogujiofor (2012), Wang (2004), Bang and Ross (2009), Surujalal and Dhurup (2008) amongst others, based on which, it identified the motivational factors driving volunteerism as: Altruistic value (AV), Love of the sport (LS), rewards \{financial, personal\} (R), Personal development \{skill, career\} (PD), Social interactions (SI), Ego enhancement (EH), Community concern/involvement (CCI).

\section{Hypotheses/Objectives}

Specifically this study sought to:

i. Identify the motivational factors driving volunteerism in the Nigeria Olympic Sport Federations.

ii. Determine the relative importance of the motivational factors driving volunteerism in the Nigeria Olympic Sport Federations.

\section{Research Design/Methodology}

This study used the AHP model (Saaty, 2000) as follows: Goal: To determine motivational factors driving volunteerism; Criteria: The motivational factors driving volunteerism as identified in literature review as stated above namely: AV, LS, R, PD, SI, $\mathrm{EH}$ and, CCI. Alternatives: The various sports federation functional/specialization areas namely: Administration, coaching, technical, sports medicine and marketing.

Figure 1: AHP Model of Motivational Factors Driving Volunteerism

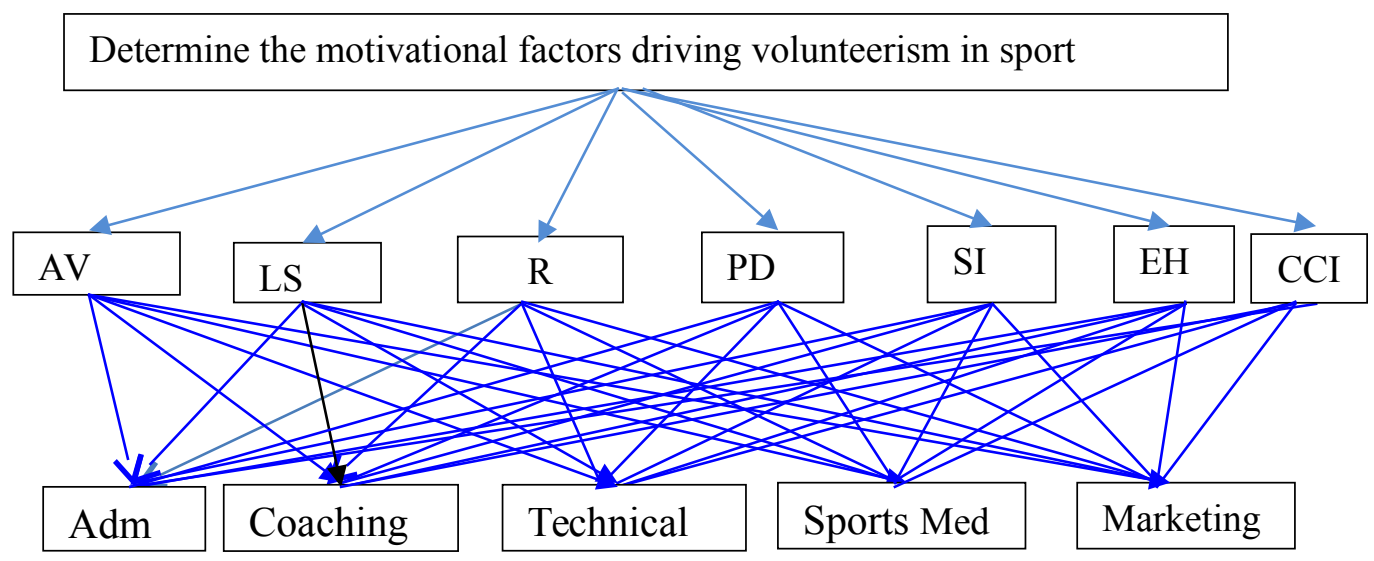

Source: Developed for this study by the authors

\section{Data/Model Analysis}

This has been written; however, given the 2 pages limitation for this abstract, it cannot be contained here but is as presented in the full paper.

\section{Limitations}

This has been written; however, given the 2 pages limitation for this abstract, it cannot be contained here but is as presented in the full paper.

\section{Conclusions}


ISAHP Article: Jagun, Dixon-Ogbechi \& Haran/Using AHP to Determine the Motivational Factors Driving Volunteerism in Sports: The Nigeria Olympic Sports Federations Experience Submitted to the International Symposium of the Analytic Hierarchy Process 2016, London, UK.

This has been written; however, given the 2 pages limitation for this abstract, it cannot be contained here but is as presented in the full paper.

\section{Key References}

Bang, H., and Ross, S. (2009). Volunteer motivation and satisfaction. Journal of Venue and Event Management, 1, 61-77.

Elendu, I. C and Egujiofor, M. (2012). Sport Volunteerism As A Tool For Effective Sports Administration And Development In Nigeria. Acad. Res. Int., 2(20:393-399. ICID:1015939.

Surujlal J.and Dhurup M. (2008). Volunteers' perceptions of benefits derived from volunteering: An empirical study. South African Journal for Research in Sport, Physical Education and Recreation. 30(1):105-11.

Wang, P. Z (2004). Assessing motivations for sports volunteerism. Advances in Consumer Research, Volume xxxi, 31, 420-425.

Saaty, T.L. (2000). Fundamentals of Decision making and Priority Theory with Analytical Hierarchy Process. Pittsburgh, PA: RWS Publications.

\section{Appendices}

Not needed for this proposal. 